\title{
THE OXFORD HANDBOOK OF
}

\section{INTERNATIONAL}

\section{ENVIRONMENTAL LAW}

Edited by

DANIEL BODANSKY

JUTTA BRUNNÉE

AND

ELLEN HEY 


\section{OXFORD \\ UNIVERSITY PRESS}

Great Clarendon Street, Oxford ox $26 \mathrm{DP}$

Oxford University Press is a department of the University of Oxford. It furthers the University's objective of excellence in research, scholarship, and education by publishing worldwide in

Oxford New York

Auckland Cape Town Dar es Salaam Hong Kong Karachi Kuala Lumpur Madrid Melbourne Mexico City Nairobi New Delhi Shanghai Taipei Toronto

With offices in

Argentina Austria Brazil Chile Czech Republic France Greece Guatemala Hungary Italy Japan Poland Portugal Singapore South Korea Switzerland Thailand Turkey Ukraine Vietnam

Oxford is a registered trade mark of Oxford University Press in the UK and in certain other countries

Published in the United States by Oxford University Press Inc., New York

(C) D. Bodansky, J. Brunnée, and E. Hey, 2007

The moral rights of the authors have been asserted Database right Oxford University Press (maker)

Crown copyright material is reproduced under Class Licence Number C01P0000148 with the permission of OPSI and the Queen's Printer for Scotland

First published 2007

All rights reserved. No part of this publication may be reproduced, stored in a retrieval system, or transmitted, in any form or by any means, without the prior permission in writing of Oxford University Press, or as expressly permitted by law, or under terms agreed with the appropriate reprographics rights organization. Enquiries concerning reproduction outside the scope of the above should be sent to the Rights Department,

Oxford University Press, at the address above

You must not circulate this book in any other binding or cover and you must impose the same condition on any acquirer

British Library Cataloguing in Publication Data

Data available

Library of Congress Cataloging in Publication Data

Data available

Typeset by Newgen Imaging Systems (P) Ltd., Chennai, India Printed in Great Britain on acid-free paper by Antony Rowe L.d., Chippenham

ISBN $978-0-19-926970-9$

13579108642 


\section{Contents}

Table of Cases

xiii

Notes on the Contributors

Xvii

Abbreviations

xxiii

1. International Environmental Law: Mapping the Field

1

Daniel Bodansky, Jutta Brunnée, Ellen Hey

\section{PART I GENERAL ISSUES}

2. The Evolution of International Environmental Law

Peter H. SAND

3. Paradigms and Discourses

JOHN S. DRYZEK

4. Global Environmental Governance as Administration:

Implications for International Law

BENEDICT KINGSBURY

5. Levels of Environmental Governance

JEFFREY L. DUNOFF

6. Formality and Informality

STEPHEN J. TOOPE

7. Relationship between International Environmental Law and Other Branches of International Law 
8. Instrument Choice

RICHARD B. STEWART

9. Science and Technology: From Agenda Setting to

Implementation

182

Steinar Andresen and Jon Birger Skjerseth

\section{PART II ANALYTICAL TOOLS \\ AND PERSPECTIVES}

10. International Relations Theory

205

Kyle W. DANish

11. An Economic Theory of International Environmental Law

SCOTt BARRETT

12. Critical Approaches

262

Karin Mickelson

13. Ethics and International Environmental Law

291

Christopher D. Stone

\section{PART III BASIC ISSUE AREAS}

14. Atmosphere and Outer Space

IAN H. Rowlands

15. Ocean and Freshwater Resources

David Freestone and Salman M.A. Salman

16. Biological Resources

Rosemary Rayfuse

17. Hazardous Substances and Activities

David A. Wirth 


\section{PART IV NORMATIVE DEVELOPMENT}

18. Different Types of Norms in International Environmental Law:

Policies, Principles, and Rules

ULRICH BEYERLIN

19. Formation of Customary International Law and General

Principles

Pierre-Marie Dupuy

20. Treaty-Making and Treaty Evolution

Thomas Gehring

21. Private and Quasi-Private Standard Setting

498

Jason Morrison and NaOmi Roht-Arriaza

\section{PART V KEY CONCEPTS}

22. Transboundary Impacts

GÜNTHER HaNDL

23. Common Areas, Common Heritage, and Common Concern JutTA BrunnéE

24. Ecosystems

Dan TARLOCK

25. Precaution

Jonathan B. WienER

26. Sustainable Development

Daniel Barstow Magraw and Lisa D. Hawke

27. Equity 
28. Environmental Rights

John G. Merrills

29. Public Participation

681

Jonas EBbESSON

30. Legitimacy

704

Daniel Bodansky

\section{PART VI ACTORS AND \\ INSTITUTIONS}

31. Changing Role of the State

Thilo Marauhn

32. International Institutions

749

ElLen Hey

33. Non-Governmental Organizations and Civil Society

770

Peter J. Spiro

34. Epistemic Communities

Peter Haas

35. Business

Steven R. Ratner

36. Indigenous Peoples

Russel Lawrence Barsh

37. Regional Economic Integration Organizations:

The European Union as an Example

LUDWIG KRÄMER

38. Treaty Bodies

Geir Ulfstein 


\section{PART VII IMPLEMENTATION \\ AND ENFORCEMENT}

39. Compliance Theory: Compliance, Effectiveness, and Behaviour Change in International Environmental Law

Ronald B. Mitchell

40. National Implementation

Catherine Redgwell

41. Technical and Financial Assistance

Laurence Boisson de Chazournes

42. Monitoring and Verification

JøRGEN WETtestad

43. Compliance Procedures

Jan KlabBers

44. International Responsibility and Liability

Malgosia Fitzmaurice

45. International Dispute Settlement

1036

Cesare P.R. Romano

Index

1057 


\section{H A P T E R 20}

\section{TREATY-MAKING AND TREATY EVOLUTION}

\section{THOMAS GEHRING}

1 Normative Development through the Establishment of New Environmental Treaty Systems

1.1 Formation of Environmental Treaty Systems

1.2 Two Characteristics of International Environmental Law-Making: Constutionalization of Environmental Treaty Systems and Institutional Fragmentation

1.2.1 Constitutionalization

1.2.2 Fragmentation

2 Policy-Making Dimension of Environmental Treaty Systems $\quad 476$

2.1 Development of International Environmental Law through Political Decision-Making within Treaty Systems

2.2 Development of International Environmental Law through Administrative Decision-Making within Treaty Systems

2.3 Technical and Scientific Expertise as a Means to Accelerate and Rationalize the Development of International Environmental Law

3 Resulting Legal Structure of Environmental Treaty Systems $\quad 485$

3.1 Normative Development through Traditional Forms of International Law

3.2 Normative Development through Simplified Amendment Procedures

3.3 Normative Development through Secondary Decision-Making 491 
INTHRNATIONAL environmental law develops predominantly through the establishment and evolution of highly dynamic environmental treaty systems. Such treaty systems are issue-specific institutional structures that are purposively established, and maintained, by their member states to govern specific areas of international environmental relations. Typically, they address collective action problems with a strong transnational, in some cases even a global, dimension. Problems of this kind cannot be addressed successfully at the domestic level, either because they have a transboundary component or because relevant countries are exploiting a common pool resource such as migratory fish, or polluting or destroying a common environmental good such as the ozone layer or a regional sea.

Environmental treaty systems are designed to facilitate and speed up the dynamic development of substantive regulations. Frequently, obligations are tightened with growing scientific and technological knowledge about a given problem and the gradual emergence of suitable abatement strategies. Dynamic treaty systems constitute hybrid structures somewhere between traditional international treaties that set forth substantive rules or standards to regulate a given area of common interest, and international organizations established for ongoing communication and decisionmaking purposes. In addition to substantive obligations, they include institutional components of varying design, which are, compared to multilateral agreements in other policy fields, remarkably strong. Typically, they contain arrangements for the adoption of new obligations, for decision-making on implementation issues, for internalizing scientific and technological information, for the review of implementation, and for the processing of cases of (alleged) non-compliance (see Chapter 38 'Treaty Bodies').

Important environmental treaty systems include:

- the 1971 Convention on Wetlands of International Importance, Especially as Waterfowl Habitat (Ramsar Convention);

- the 1972 Convention on the Prevention of Marine Pollution by Dumping of Wastes and Other Matter (London Convention);

- the 1972 Convention on International Trade in Endangered Species of Wild Flora and Fauna (CITES);

- the 1976 Convention on the Protection of the Mediterranean Sea against Pollution (Barcelona Convention) and its several protocols;

- the 1979 Convention on Long-Range Transboundary Air Pollution (LRTAP Convention) and its eight protocols to date;

- the 1985 Convention for the Protection of the Ozone Layer (Vienna Convention) and the 1987 Montreal Protocol on Substances That Deplete Ozone Layer (Montreal Protocol);

- the 1989 Convention on the Control of Transboundary Movement of Hazardous Wastes (Basel Convention) and the 1999 Protocol on Liability and Compensation;

- the 1992 United Nations Framework Convention on Climate Change (UNFCCC) and the 1998 Kyoto Protocol to the UNFCCC (Kyoto Protocol); 
- the 1992 Convention on Biological Diversity (CBD) and the 2000 Cartagena Protocol on Biosafety (Cartagena Protocol); and

- the 1992 Convention on the Protection and Use of Transboundary Watercourses and Lakes.

This chapter examines how the establishment and operation of treaty systems such as these helps to create and develop international environmental law. Section 1 inquires into the emergence of environmental treaty systems and identifies two characteristics of the evolving law-making structure: first, the 'constitutionalization' of treaty systems through the creation of new structures for the making of international environmental law, and, second, the institutional fragmentation of international environmental governance. Section 2 examines the policy-making dimension of environmental treaty systems and identifies three areas of intra-institutional activity relevant to the law-making process: broadening and tightening commitments over time; elaborating upon, and in some cases redefining, existing obligations through an administrative process; and undertaking scientific and technical assessments to reinforce and accelerate normative development. Section 3 explores the output of the law-making process, arguing that different types of law emerge. Whereas regular treaty law is still the most important single output of environmental law-making, it is supplemented by law emerging from simplified amendment procedures and secondary decisions of competent treaty bodies.

\section{Normative DeVelopment THROUGH THE ESTABLISHMENT OF NEW Environmental Treaty Systems}

\subsection{Formation of Environmental Treaty Systems}

Deliberate international governance requires arrangements for collective decisionmaking. Tacitly emerging social norms, whether legally binding or not, can merely reflect, and subsequently stabilize, the existing behaviour of their addressees (see Chapter 19 'Formation of Customary International Law and General Principles'). If social norms are to be used to change an undesirable status quo, they must be molded prior to the action that they are intended to guide. ${ }^{1}$ States intending to establish governance for an area of international relations must organize themselves, and acquire the ability to decide collectively upon social norms that indicate desired

\footnotetext{
' On the difference between spontaneous and negotiated regimes, see O.R. Young, 'Regime Dynamics. The Rise and Fall of International Regimes' (1982) 36 Int'l Org. 277 at 282-3.
} 
behaviour. To understand how international environmental treaty law is made and developed, it is important to note that every deliberately designed international rule is inevitably related to some organizational component. It can emerge from a simple diplomatic conference or from some more complex organizational structure governing an area of international relations (see Chapter 32 'International Institutions').

Environmental treaty systems originate from inter-governmental negotiations. The traditional organizational arrangement for deliberate international governance is the temporarily established diplomatic conference. A diplomatic conference is convened when a group of actors so desires, and dissolved upon the adoption of the final act of the conference to which the treaty is attached. Alternatively, a treaty may be prepared within an existing international organization and adopted by a separately convened diplomatic conference or by a negotiating committee. Occasionally, a treaty is not only elaborated within, but also adopted by a decision of, an international organization. In all cases, the treaty is subsequently opened for signature by states and enters into force upon ratification by the number of states required by the treaty.

Decision-making in treaty-making negotiations on environmental issues, in practice, relies predominantly on the consensus principle. While frequently not even formally defined, consensus may be conceived of as the absence of any objection by a representative and submitted by him as constituting an obstacle to the taking of the decision in question.'2 Conceptually, it is located somewhere between unanimity and majority voting. Like the former, it preserves the right of all parties to reject an undesired decision, but, like the latter, it does not require a positive vote by all parties. Whereas decisive actors can pursue their interests, indifference is treated as agreement. Hence, consensus decision-making requires active intervention in the negotiation process before the final decision is adopted. ${ }^{3}$ What is more, decisions are not made by casting votes, but are developed through the gradual removal of objections against particular aspects of a draft treaty (often indicated by the bracketing of text). Settlements that are achieved are difficult to challenge later in the process because indifferent actors will tend to have accommodated themselves with the result so that support grows.

Before a negotiation process can start, pre-decisions have to be made about the relevant group of participating actors and the range of issues to be discussed. The problems of international relations are not simply 'given', but are, at least to some degree, 'socially constructed'. Accordingly, the subject of the negotiations and the emerging issue-area of the future environmental treaty system can, to some degree, be deliberately designed. Usually, the process will start with concern by interested

\footnotetext{
2 Quoted from J.Sizoo and R.T. Jurjens, CSCE-Decision-Making: The Madrid Experience (The Hague: Martinus Nijhoff, 1984) at 57 .

${ }^{3}$ On the implications of consensus decision-making, see B. Buzan, 'Negotiating by Consensus: Developments in Technique at the United Nations Conference at the Law of the Sea' (1981) 75 A.J.I.L. 324 at $324-47$.
} 
actors about some undesirable development, which they believe can be remedied by international cooperation. For example, during the 1980 s an epistemic community of atmospheric scientists succeeded in bringing the problem of global climate change onto the international agenda (see Chapter 14 'Atmosphere and Outer Space'). In defining the problem as a subject of international negotiations, numerous questions then had to be addressed. Should the climate regime address adaptation as well as mitigation? Should it aim at binding national targets and timetables to reduce greenhouse gas emissions or at the development of specific policies and measures? Should it focus on all greenhouse gases or just carbon dioxide? Should it treat climate change as a task mainly for cooperation among industrialized countries or as a matter of global concern? Should it be considered as just another aspect of the overall problem of protecting the global atmosphere or as a separate subject of international relations?

The delimitation of issues and actors has an immediate effect on the constellation of interests upon which substantive compromise will eventually be founded. ${ }^{4}$ Negotiation theory demonstrates that adding or subtracting issues and parties changes opportunities for actors to pursue their interests. Since no round of international negotiations, however broadly designed, can tackle all problems between all states, numerous pending issues are excluded from a negotiation. Actors may favour different delimitations of the emerging issue-area because they cannot successfully pursue interests related to excluded issues. They can expect concessions only from those actors participating in the negotiation round. Generally, an issue area must be sufficiently broad to allow for cooperation gains of all relevant parties, but it does not have to include all substantively related issues. Likewise, the group of participating actors must be sufficiently large to allow meaningful cooperation and will usually have to include the major players in the field, but it does not have to be all-inclusive. Even global problems might be successfully tackled, at least temporarily, by a comparatively small group of actors. Despite the global nature of the problem, the Montreal Protocol was adopted at a conference attended by 58 states and the European Community, and it was immediately signed by only 25 states and the European Communityincluding, however, most major polluters.

The initiation of a new environmental treaty system within the framework of an existing international organization, rather than through a separately established diplomatic conference, can considerably lower the organizational costs of an intergovernmental negotiation process. These costs increase dramatically with the number of states involved. They include the preparation of documents in, and the translation of discussions into, usually several conference languages as well as the procedural organization of the conference process. Existing organizations provide room for the occasionally lengthy pre-negotiation of the precise terms of references

4 J.K. Sebenius, 'Designing Negotiations toward a New Regime: The Case of Global Warming' (1991) 15 Int'I Security 110 at $110-48$. 
of the newly established negotiation process, and will thus legitimize an initiative if a mandate is agreed upon according to established procedures. In the absence of a suitable organizational framework, one or more interested states not only have to take the political initiative, they must also be prepared to organize and invite an intergovernmental conference and provide servicing functions.

The clearly defined memberships of established international organizations, and their specific agendas and organizational cultures, open opportunities for forum shopping and may lead to lengthy struggles over the choice of the appropriate forum. The most pertinent example of forum shopping is the decade-long struggle of the Nordic countries to put the issue of long-range transboundary air pollution on the international agenda. Originating in the 1960 s as a bilateral issue between these countries and the United Kingdom, transboundary air pollution was introduced first into the Council of Europe, then into the Organisation for Economic Cooperation and Development (OECD), and finally into the Conference on Security and Cooperation in Europe and the UN Economic Commission for Europe (UNECE). Only the latter pan-European context, with its close linkage to the highly political issues of East-West relations as well as the involvement of the United States and Canada, provided the foundation for the adoption of the LRTAP Convention in 1979. In other cases, countries with diverging interests struggle over the appropriate forum. Hence, negotiations on the UNFCCC were launched by the UN General Assembly rather than by the UN Environment Programme (UNEP) because developing countries advocated a close link between the issues of environmental protection and economic development. And the regulation of trade restrictions for genetically modified organisms was disputed between the World Trade Organization (WTO), with its Agreement on Sanitary and Phytosanitary Measures, and the CBD with its Cartagena Protocol. 5

Most global and larger regional environmental treaty systems have been established within the framework of an existing international organization or similar international structure. Most important has been UNEP, which is not a formally independent international organization, but a programme under the auspices of the UN General Assembly. UNEP has been the catalyst for such important environmental treaty systems as the Vienna Convention and its Montreal Protocol, the Basel Convention, the $\mathrm{CBD}$, and several regional seas conventions protecting, inter alia, the Mediterranean and the Red Sea. As already mentioned, the UNFCCC negotiations were initiated by the UN General Assembly. Two important global conventions of the early 1970s, namely CITES and the London Convention, were negotiated as part of the broader process associated with the 1972 United Nations Conference on the Human Environment, which was organized by the United Nations and also led to the

\footnotetext{
5 See S. Oberthür and T. Gehring, 'Institutional Interaction in Global Environmental Governance: The Case of the Cartagena Protocol and the World Trade Organization' (2006) 6 Global Envt'l Pol. 1.
} 
creation of UNEP. Other treaty systems originated from more specialized organizations. The International Maritime Organization (IMO) provided the institutional framework for several conventions on marine pollution from ships, including accidental oil spills. And the UNECE assisted in the establishment of the 1979 LRTAP Convention and the Convention on the Protection and Use of Transboundary Watercourses and Lakes. Only a few modern environmental treaty systems were established without the assistance of an existing institutional structure. This has been the case especially for sub-regional cooperative projects with a limited membership, for which no appropriate multi-purpose organization exists, such as the Convention for the Protection of the River Rhine, the Convention for the Prevention of Marine Pollution by Dumping from Ships and Aircraft (Oslo Convention), the Convention for the Prevention of Marine Pollution from Land-Based Sources (Paris Convention), and the Convention on the Protection of the Marine Environment of the Baltic Sea Area (Baltic Sea Convention).

\subsection{Two Characteristics of International Environmental Law-Making: Constutionalization of Environmental Treaty Systems and Institutional Fragmentation}

\subsubsection{Constitutionalization}

An important characteristic of international environmental governance is the gradual constitutionalization of environmental treaty systems. Almost all modern environmental treaty systems create their own institutional apparatuses (see Chapter 38 'Treaty Bodies'). A few treaty systems, such as the Baltic Sea Convention and the Oslo and Paris Conventions, establish fully independent small-scale international organizations, while some others draw entirely upon the decision-making bodies and secretariat of their parent organization (for example, the marine conventions administered by the IMO). Most environmental treaty systems lie somewhere in between, retaining a relationship to their parent organization but having their own identity as well. Typically, a conference of the parties in which all member states are represented constitutes the supreme decision-making body. Many environmental treaty systems establish a secretariat that is financed by the member states and supervised by the conference of the parties, while being hosted by the parent organization. This arrangement can be attributed to the fact that many of the important treaty systems of the 1970 s and 1980 s emerged either from loose institutional settings such as the UN Conference on the Human Environment or from UNEP with its restricted budget. Thus, the Ramsar Convention and CITES were facilitated until the mid-1970s by UNEP, but members were then asked to provide their own funding. Later treaty systems such as the Vienna Convention and its 
Montreal Protocol, the Basel Convention, as well as several regional seas conventions, from the beginning provided for their own administrative budgets and secretariat functions, while being attached to UNEP to avoid the creation of numerous fully independent mini-organizations.

The establishment of a permanent decision-making apparatus as a part of a modern environmental treaty system has been a consequence of negative experience with the more static arrangements of some early multilateral environmental agreements, especially in the area of the protection of nature and wildlife. It is widely seen as a major drawback that 'sleeping treaties', ${ }^{6}$ such as the 1940 Convention on Nature Protection and Preservation in the Western Hemisphere, and the 1968 African Convention on the Conservation of Nature and Natural Resources, did not create their own institutional components, including appropriate arrangements for flexible amendment and administration. A decision-making arrangement with a mere temporary existence such as a diplomatic conference or a preparatory committee is generally not particularly well-suited for international environmental governance because substantive treaty law must then be designed so as to regulate a subject matter so comprehensively that further decisions are dispensable. In institutional economics, such an arrangement is called a 'complete contract'-in contrast to an 'incomplete contract' that deliberately leaves certain matters to subsequent decisionmaking. ${ }^{7}$ Although it does not exclude amendments negotiated at further diplomatic conferences or within newly established preparatory committees (see section 3.1), the flexibility of a treaty system is thereby sharply limited.

Institutional flexibility is needed because transnational environmental problems develop dynamically, and constitute a highly unstable subject matter for regulation. They are created, and solved, by human economic activity, which depends on such factors as economic growth, technological development and changing preferences. Early attempts to regulate an environmental problem are frequently initiated under conditions of scientific uncertainty. Even highly complex substantive rules cannot be designed to account for all possible future developments within the regulated issue area. Moreover, in the absence of a permanent institutional apparatus, international treaties do not provide for arrangements for collective implementation review and conflict management. Since successful environmental governance frequently requires costly investments by states and their subjects, it regularly creates incentives for free riding and may even over-stretch the capacities of member states for action. ${ }^{8}$

As a consequence of their organizational arrangements, modern environmental treaty systems become themselves machineries for the making and development of international environmental law. Despite the frequent retention of links to an

- S. Lyster, International Wildlife Law: An Analysis of International Treaties Concerned with the Conservation of Wildife (Cambridge: Grotius Publications, 1985) at 124.

7 See O.E. Williamson, The Economic Institutions of Capitalism (New York: Free Press, 1987) at 178.

s A. Chayes and A. Handler Chayes, The New Sovereignty: Compliance with International Regulatory Agreements (Cambridge, MA: Harvard University Press, 1998). 
existing international organization, many treaty systems have become virtual organizations for the management of substantive international treaties. Even if a treaty system draws upon an existing organization, this organization derives its decisionmaking competence from the respective treaty system. Once established, the member states may introduce specialized decision procedures that may deviate considerably from the original negotiation situation and involve scientists, experts, and nongovernmental organizations. By delegating certain powers to the new entity, member states 'constitutionalize' governance within a given area of international relations.

\subsubsection{Fragmentation}

The second characteristic of international environmental governance is its institutional fragmentation. International environmental law encompasses more than 200 separately established environmental treaty systems. In contrast, the institutional landscape is much less fragmented in other problem areas such as international trade. The absence of a single international environmental organization may be attributed to the fact that most large-scale international organizations were established around the end of the Second World War, whereas international environmental affairs as a specific area of international governance developed mainly after 1970.

Although the lack of an overarching institution is frequently deplored and has led to demands for the establishment of a World Environment Organization, institutional fragmentation arguably reflects a strength, rather than a weakness, of international environmental governance. There may simply be no real need for a single comprehensive organization because many environmental problems are best tackled separately from others. It is difficult to see how lumping together several separately institutionalized treaty systems could significantly increase the opportunities for cooperation. Interests in such large issue-areas as international trade or law of the sea are often asymmetrically distributed, so that actors seek advantages on one issue while giving concessions on another. In contrast, interests regarding major environmental problems are frequently symmetrically distributed so that all actors must adopt similar measures (reduce pollution) to enjoy similar benefits from the preservation of a global or regional common (for example, the protection of the global climate, the ozone layer, or a regional sea). Linking such issues would primarily enhance the complexity of negotiations rather than create new opportunities for cooperation. Under these circumstances, the absence of a single international environmental organization allows states to design institutional arrangements tailor-made to the specific needs of a particular cooperation project.

The far-reaching institutional fragmentation of international environmental governance leads to increasing interaction between different treaty systems. Institutional interaction occurs in very different forms. ${ }^{9}$ It may create synergy

\footnotetext{
9 S. Oberthür and T. Gehring, eds., Institutional Interaction in Global Environmental Governance: Synergy and Conflict among International and EU Policies (Cambridge, MA: MIT Press, 2006).
} 
between the institutions involved or disrupt the governance effort. On the one hand, the normative development within one institution can influence the normative development within another system. This will be true if a regional treaty system (for instance, the (Oslo Convention) influences normative development in a similarly focused global system (for example, the London Convention); or if institutional innovations invented within one treaty system, such as non-compliance procedures or simplified amendment procedures, are adopted by others; or if states establish a separate institution (for example, the International North Sea Ministerial Conferences) in order to influence an existing treaty system (for instance, the Oslo Convention). On the other hand, one treaty system can influence the behaviour of states and non-state actors relevant to the implementation of another treaty system. This would be the case to the degree that incentives created under the UNFCCC and its Kyoto Protocol to plant fast-growing trees as sinks of carbon dioxide discourage the preservation and expansion of species-rich traditional forests and thereby hamper the implementation of the CBD. ${ }^{10}$

\section{Policy-Making Dimension of Environmental Treaty Systems}

Many environmental treaty systems rely on an explicit step-by-step approach that does not aim at the comprehensive solution of a larger problem at once, but at the rapid conclusion of a set of initial instruments and the establishment of a policymaking process directed at preparing further instruments. The regulatory approach of environmental treaty systems differs significantly from that pursued in other policy fields. Instruments tend to codify realistic targets, accompanied by the expectation of sincere implementation and the opportunity to tighten obligations, if possible. With a view towards possible revision, they include provisions for the regular review of substantive obligations and for possible decisions on additional measures in light of new scientific, economic, and technological information. This approach contrasts starkly with human rights conventions, which tend to codify comprehensive catalogues of obligations and create enormous implementation deficits. And negotiations of the UN Conference on the Law of the Sea illustrated that an overall approach linking numerous separate issues to a package of overwhelming size and complexity might lead to cumbersome and time-consuming negotiations, with a significant risk of failure.

10 See C.P. Pontecorvo, 'Interdependence between Global Environmental Regimes: The Kyoto Protocol on Climate Change and Forest Protection' (1999) 59 Zeitschrift für ausländisches öffentliches Recht und Völkerrecht 709 at $709-49$. 
The permanent law-making process not only blurs the distinction between the making and the implementation of law because later and more specific rules and decisions refine and reinterpret earlier and more general rules. It also opens the opportunity for feedback processes, through which a treaty system can adjust policy measures to the effects of its own governance activities, so as to increase its own effectiveness. ${ }^{11}$

\subsection{Development of International Environmental Law through Political Decision-Making within Treaty Systems}

The substantive obligations of almost all important treaty systems have significantly changed over time. The Montreal Protocol, which was adopted in 1987, has been amended in 1990, 1992, 1997, and 1999 in order to gradually tighten the reduction schedules for ozone-depleting substances, to extend its regulatory measures to new substances, and to introduce new supporting measures, most important of which is the introduction of a multi-million dollar multilateral fund for the financial support of developing countries. Likewise, the LRTAP Convention has adopted a whole series of protocols that have gradually expanded the scope of the regime from the control of a single pollutant, namely sulphur dioxide, to virtually all important air pollutants. The regulatory approach of the Basel Convention has been transformed from a licensing system for the international trade of hazardous wastes based upon prior informed consent into an almost total ban of exports from OECD countries to nonOECD countries. Regulation under the London Convention has been expanded to cover sources of marine pollution such as the incineration of wastes at sea and to phase out the dumping of industrial and radioactive wastes. And CITES regularly applies its trade-restricting measures to newly endangered species of flora and fauna and has also developed new regulatory approaches, such as quota systems, which are not envisaged within the treaty itself. ${ }^{12}$

Originally, flexibility was achieved through the split between the general obligations in the main body of a treaty and more specific rules set forth in an allegedly technical annex, which was frequently subject to a simplified amendment procedure. The 1946 International Convention for the Regulation of Whaling (Whaling Convention) was one of the first treaties to take this approach, setting forth detailed regulations in a schedule that can be amended by qualified majority vote. Similarly, CITES and the London Convention set forth their core obligations in their main

\footnotetext{
"See T. Gehring, Dynamic International Regimes: Institutions for International Environmental Governance (Frankfurt: Peter Lang, 1994) at 443-8.

12 See P.H. Sand, 'Commodity or Taboo? The Regulation of Trade in Endangered Species' (1997) 6 Green Globe Y.B. 19 at 21-4.
} 
body, while their annexes specify protected species of flora and fauna and regulated types of ocean dumping respectively. The International Convention for the Prevention of Pollution from Ships (MARPOL Convention), which was adopted in $1973 / 78$, claborated this model by including both mandatory and voluntary annexes.

More recently, the adoption of protocols subsidiary to existing conventions has become the most important method for the development of treaty law. The convention-protocol approach has been specifically developed to support the stepby-step approach of environmental governance. The Barcelona Convention-the first and most important project within UNEP's regional seas programme-was deliberately designed as an umbrella treaty, whose ratification was conditional upon the simultaneous acceptance of two substantive protocols, while other protocols are voluntary. So far, five protocols have entered into force and two more have been adopted. Under the 1979 LRTAP Convention, eight protocols have entered into force. These two treaty systems have developed the greatest virtuosity in employing the convention-protocol arrangement to deepen and broaden their respective regulatory approaches. The ability to agree on new sets of obligations has regularly led to the adoption of new instruments. Likewise, the Montreal Protocol, the Kyoto Protocol, and the Cartagena Protocol have supplemented the Vienna Convention, the UNFCCC, and the CBD respectively.

The convention-protocol approach increasingly reverses the original relationship between the substantive and the institutional components of a treaty system. In earlier treaties, such as the previously mentioned London Convention and CITES, the procedural machinery and auxiliary rules concerning negotiation, information, and reporting were included in conventions subsequent to agreement on substantive obligations in order to ensure that the obligations were implemented and developed. More recently, the adoption of framework conventions in the absence of substantive obligations has become a vehicle for the development of substantive obligations and their acceptance. Whereas ratification of the Barcelona Convention was still conditional upon the simultaneous acceptance of two substantive protocols, the adoption of the LRTAP Convention reflected continued disagreement among the member states about meaningful commitments to reduce the emission of key air pollutants. The parties merely agreed to establish a separate process and the necessary institutional machinery for the making of international environmental law regulating longrange transboundary air pollution as well as duties to cooperate, to report, and to provide information. Likewise, the Vienna Convention merely established the institutional machinery of the treaty system and some auxiliary obligations, because the participating states, in 1985 , could not agree on hard obligations to reduce emissions of ozone-depleting substances. During negotiation of the UNFCCC in 1992, disagreement once again prevented the adoption of a clause that would have committed the parties to stabilizing their carbon dioxide emissions, so that this instrument also lacks hard substantive obligations.

By concluding a framework convention as a first step of an evolutionary regulatory process, states deliberately modify the subsequent negotiation situation in a number 
of ways. On the one hand, bargaining will be more institutionalized than before. The convention establishes the negotiation situation for the subsequent deliberations on substantive obligations. It defines the problem to be addressed in general terms, and it delimits the group of actors that are entitled to participate in the ensuing negotiations. Since the convention establishes the basic principles, institutions, and decision-making mechanisms, later protocols might be very concise, depending on the complexity of their regulatory approach. On the other hand, agreement on, and entry into force of, a framework convention generates permanent pressure on reluctant member states to reconsider their positions. Hence, the UNFCCC requires governments to develop greenhouse gas inventories, to formulate national strategies and measures, and to cooperate in scientific research on the problem. Due to the ongoing policy process, governments are continuously confronted with demands by other states and, increasingly, by domestic stakeholders to cooperate, and they are routinely forced to face new, or collectively evaluated, scientific insights. Such pressure appears to be more easily organized within a well-established institutional structure than, say, in the framework of a multi-purpose international organization or a separately gathered diplomatic conference. ${ }^{13}$

Since framework conventions, being full-fledged international treaties, require time-consuming domestic ratification, member states tend to start the permanent process of negotiating new environmental law even before the convention has formally entered into force. Such 'interim mechanisms' emphasize the importance of the process component, focusing on the development of future law, as compared to the mere implementation of the substance already agreed upon.

\subsection{Development of International Environmental Law through Administrative Decision-Making within Treaty Systems}

The development of international environmental law is also driven by permanent decision-making activities beyond the occasional adoption or regular amendment of treaties. Although these activities are usually considered as management or implementation of treaty provisions, they have important implications for the development of international environmental law and its effectiveness. Moreover, since such 'administrative' decision-making may be governed by more complex decisionmaking procedures, it can affect the process of law-making and, arguably, also the

\footnotetext{
${ }^{13}$ For criticisms of the idea that treaty systems start with non-substantive obligations and evolve over time, see G.W. Downs, K.W. Danish, and Peter N. Barsoom, 'The Transformational Model of International Regime Design: Triumph of Hope or Experience?' (2000) 38 Colum. J. Transnat'l L. 465 at 465-514; and L.E. Susskind, Envirommental Diplomacy: Negotiating More Effective Global Agreements (New York: Oxford University Press, 1994) at 30-7 (arguing that the convention-protocol approach is 'fundamentally flawed' and attributing many general complications of treaty systems to this approach).
} 
content of the resulting decisions. Virtually all modern environmental treaty systems provide the institutional framework for the adoption of administrative decisions of various kinds for the filling of gaps in the treaty law or for its formal or informal adjustment to changed circumstances (see Chapter 4 'Global Environmental Governance as Administration').

Regular administrative decision-making permanently renews normative expectations and bridges unexpected gaps of treaty law so as to avoid doubt about common obligations and preclude their unilateral interpretation. Such decisions reassure the members of the treaty system of the normative expectations held by the entire community of member states about their behaviour. They shape and re-shape normative agreement and reestablish the commitment entered into previously. For example, at the request of the Soviet Union, the Montreal Protocol had permitted, under certain circumstances, an increase in the production of ozone-depleting substances beyond 1986 levels. The Meeting of the Parties (MOP) 'decided' by consensus that such a production increase may not be used for export to non-parties of the protocol. ${ }^{14}$ Similarly, the executive body of the LRTAP Convention bridged a gap in the first sulphur dioxide protocol by way of interpretation. While parties were committed to reduce their sulphur dioxide emissions by at least 30 per cent by 1993 , the protocol did not address the period after 1993. Therefore, the executive body 'noted a common understanding among the Parties'15 that an increase in such emissions after 1993 would be inconsistent with the protocol.

Administrative decision-making is also employed to relieve treaty-making negotiations from numerous tasks that could in principle also have been dealt with at the outset. It constitutes a means to accelerate the conclusion of a negotiation and to postpone the settlement of pending conflicts. The Montreal Protocol (Article 8) and its London Amendment (Article 10.1) assigned the task of adopting a noncompliance procedure and an indicative list of incremental costs to be financed by the financial mechanism to the MOP of the Montreal Protocol. ${ }^{16}$ The Kyoto Protocol explicitly assigns a whole range of tasks to the MOP, including the elaboration of rules regarding emissions trading, the clean development mechanism, and the crediting of sink activities. These decisions were provisionally adopted in 2001 by the Conference of the Parties (COP) of the convention in the form the Marrakesh Accords' and were formally adopted by the first MOP of the Kyoto Protocol in 2005.

Likewise, administrative decision-making is occasionally employed to rapidly develop an environmental treaty system though the adoption of decisions that are not expressly provided for in the respective treaties. The MOP of the Montreal Protocol established in 1990 an interim multilateral fund by a simple 'decision'

14 Decision I.12G, Report of the Parties to the Montreal Protocol on the Work of Their First Meeting, Doc. UNEP/OzL.Pro.1/5 (6 May 1989).

15 See Report of the Seventh Session of the Executive Body, Doc. ECE/EB.AIR/20 (1989) at para. 22.

${ }^{16}$ Adopted by Decisions IV/18 and IV/5, Report of the Fourth Meeting of the Parties to the Montreal Protocol on Substances that Deplete the Ozone Layer, Doc. UNEP/OzL.Pro.4/15 (25 November 1992). 
without a specific competence. The decision, adopted by consensus, was part of a broader agreement that paved the way for the accession of important developing countries. ${ }^{17}$ Without a specific competence, the COP of CITES has, over time, adopted various law-making decisions, which are apparently intended to, and seem to be regarded as, formally committing the member states. The regulatory approach of the Basel Convention was first thoroughly changed by a decision of the COP of the Basel Convention that replaced the original system of prior informed consent by a ban of exports of hazardous wastes from OECD countries to non-OECD countries. ${ }^{18}$

Finally, administrative decision-making may create soft law instruments, if the adoption of hard law proves to be impossible. When support by the member states increases, their content may be transferred into hard law later on. Especially under the London Convention, legally binding obligations have repeatedly been preceded by recommendations. Hence, a recommendation of 1983 to prohibit the dumping of radioactive waste only became formal treaty law in 1993. Likewise, the amendments to the convention to phase out the incineration of wastes at sea and the disposal of industrial wastes at sea had been prepared by soft law instruments. Under the Montreal Protocol, the comparatively weak original control measures were first tightened by the Helsinki Resolution of 1989, before the new obligations became part of the first amendment adopted in 1990.

The increasing relevance of such administrative decision-making has changed the nature of environmental treaty systems and the process of environmental lawmaking. There is an implicit trade-off between the complexity of substantive regulation in the original treaty and the relevance of secondary law-making. The more detailed the substantive regulations of the treaty are, the less room exists for subsequent decision-making that might generate momentum of its own and the more traditional the legal development of the treaty system will be-and vice versa. The less elaborate the substantive treaty rules are and the more actors resort to postponing decisions to later stages of the governance process, the more important the institutional component of the arrangement will be from which such later decisions emerge and the more flexibly will the environmental law governing the issue area in question develop. Hence, the two levels of law-making become-to some degreefunctional equivalents- that is, actors can increasingly choose the level at which they will deal with a given problem.

\footnotetext{
17 In order to establish the fund on a permanent basis, however, the parties did not rely merely on a MOP decision, but rather did so by means of the London Amendment, which has in the meantime entered into force. See H. Ott, "The Montreal Protocol: A Small Step for the Protection of the Ozone Layer, a Big Step for International Law and Relations' (1991) 24 Verfassung und Recht in Ubersee 188 . The size of the fund was US \$160-240 million for a three-year period.

${ }^{18}$ However, the legal force of this decision was disputed by some member states. Therefore, the COP adopted at a later session an amendment to the convention, which is not yet in force. See Decision II/12, Report of the Second Meeting of the Conference of the Parties to the Basel Convention on the Control of Transboundary Movements of Hazardous Wastes and Their Disposal, Doc. UNEP/CHW.2/30 (25 March 1994); and Decision III/1, Decisions Adopted by the Third Meeting of the Conference of the Parties to the Basel Convention, Doc. UNEP/CHW.3/35 (28 November 1995).
} 
Administrative decision-making does not necessarily have to involve all parties to a treaty system. It may also rely upon true delegation of decision-making competencies to committees or more complex decision-making arrangements. Decisions to classify endangered species of flora and fauna under CITES are guided by extensive criteria, and pass through a multi-tier procedure that assigns an important role to the Secretariat. The member states of the Montreal Protocol went a step further, and assigned decisions on funding to an Executive Board comprised of a limited number of developing and developed countries. Funds are allocated according to an indicative list of incremental costs, so that decisions are based on comparatively well-defined criteria. ${ }^{19}$ Probably the most impressive administrative apparatus is currently established under the Kyoto Protocol for the approval, management, and control of projects under the clean development mechanism, which allows developed countries to obtain certified emission reduction credits from projects located within developing countries. This system of administrative decision-making is accountable to the MOP and operates under its general supervision and guidance. ${ }^{20}$ However, it is designed so as to preclude immediate intervention of the political body into case-specific decision-making.

Arrangements involving true delegation are usually designed to remove certain decisions from intergovernmental bargaining and to ensure rule-based decisionmaking. They are well known from (semi-) independent regulatory agencies within the European Union and domestic political systems. Acceptance of resulting decisions does not rely on the consent of all parties to their precise content, but rather on the legitimacy of the procedural arrangement and the expectation that decisions can be justified by convincing arguments (see Chapter 30 'Legitimacy'). In essence, these procedures are designed to transform power-based bargaining into reason-based arguing. They rely on a division of two decision-making functions. First, general decision criteria and procedures for case-specific decision-making are elaborated. At this stage, stake-holders are at least partially hindered from acting according to their case-specific interests because any rules and procedures that they elaborate will apply to numerous different and possibly still unknown cases-thus creating a partial Rawlsian 'veil of ignorance.21 Under these conditions actors will tend to promote well-operating procedures and fair-that is, non-discriminating-substantive

19 F. Biermann, 'Financing Environmental Politics in the South: Experiences from the Multilateral Ozone Fund' (1997) g Int'l Envt'l Affairs 179.

20 See Modalities and Procedures for a Clean Development Mechanism, as defined in Article 12 of the Kyoto Protocol, Decision 17/CP. 7 , Report of the Conference of the Parties on Its Seventh Session, Marrakesh, 29 October-10 November 2001: Addendum: Part Two: Action Taken by the Conference of the Parties, Volume II., Doc. FCCC/CP/2001/13/Add.2 (21 January 2002); and Guidance to the Executive Board of the Clean Development Mechanism, Decision 21/CP. 8, Report of the Conference of the Parties on Its Eighth Session, New Delhi, 23 October-1 November 2002: Addendum 3. Part Two: Action Taken by the Conference of the Parties at Its Eighth Session, Doc. FCCC/CP/2002/7/Add.3.

21 J. Rawls, A Theory of Justice, 12 th edition (Cambridge, MA: Harvard University Press, 1980) at $136-42$. 
criteria. Subsequently, the room for discretion, in which interest-based bargaining and political maneuver might ensue, will be limited so that rule-based arguments about the most appropriate option can dominate case-specific decisions.

\subsection{Technical and Scientific Expertise as a Means to Accelerate and Rationalize the Development of International Environmental Law}

As the development of international environmental law depends heavily on the proper scientific understanding of environmental problems, and the availability of technical solutions, all modern environmental treaty systems are designed to actively shape, in one form or another, widely accepted cognitive expectations on the scientific or technological background of political action (see Chapter 9 'Science and Technology'). In most cases, the scientific and technological assessment apparatus of environmental treaty systems do not conduct primary research. Predominantly, they evaluate available information and produce a body of knowledge that is commonly agreed within the treaty system and, thus, is more accepted than information fed into the process by any actor because it has been scrutinized by multinational teams of experts. Perhaps the most impressive example is the European Monitoring and Evaluation Programme (EMEP) of the LRTAP Convention. It was originally established to assess the import-export budgets of certain air pollutants, beginning with sulphur dioxide, for all European member states but was later employed to allocate emission targets to the member countries. ${ }^{22}$ Similarly, under the Vienna Convention, existing information on the atmospheric chemistry of ozone depletion and the nature of ozone-depleting substances and their substitutes is regularly assessed. Likewise, the ground for the regulation of climate change was prepared by the Intergovernmental Panel on Climate Change, which continues to serve as the informal scientific and technological branch of the climate change negotiations, despite the lack of a formal relationship to the UNFCCC.

The organized assessment of the scientific and technological aspects of an environmental problem accelerates law-making because it allows the institutionalized policy-making process to start before the nature of an environmental problem, and the interests of possible contracting parties, have become clear. In general, political decision-makers will not agree on costly obligations to protect the environment, and abate pollution, until they have reliable information about the importance of a given problem. Scientific and technological assessments can help provide the prerequisites for the political acceptance of meaningful substantive obligations. Research activities

\footnotetext{
${ }^{22}$ R.R. Churchill, G. Küttig, and L.M. Warren, 'The 1994 UNECE Sulphur Protocol' (1995), 7 I. Envt'l
L. 169 at $182-6$.
} 
on long-range transboundary air pollution started long before it had become clear from where the deposits of air pollutants in a given country originated, and to where the emissions were exported. Likewise, the regulation of ozone-depleting substances was preceded by the Co-ordinating Committee on the Ozone Layer, a scientific and technological structure within the framework of UNEP that assessed existing information on the atmospheric chemistry of ozone depletion, and the nature of ozonedepleting substances and their substitutes.

The assessment of environmental problems and their solutions affects the nature of international environmental law-making because it assigns an important role within the law-making process to experts, including those from nongovernmental organizations and industry. 'Epistemic communities' that evolve around environmental treaty systems, frequently include both governmental and non-governmental experts (see Chapter 34 'Epistemic Communities'). Within the LRTAP Convention, EMEP was closely supervised by governmental experts, whereas the regional air pollution information and simulation model on which later regulatory approaches were based was elaborated by non-governmental scientists of the International Institute of Applied Systems Analysis in Laxenburg, Austria. During the contentious early negotiations on the Montreal Protocol, a technological assessment panel was established to bring together experts from different branches of industry, in particular, the users of ozone-depleting substances and the producers of substitutes, in order to generate common knowledge on the uses for which marketable substitutes existed. Likewise, experts from diverse nature protection NGOs are heavily involved in the assessment of endangered species within the framework of CITES.

Successful scientific and technological assessment separates two distinct functions from each other, namely the shaping of cognitive expectations on scientific and technological matters and the (subsequent) shaping of political consensus among the contracting parties. The assessment of scientific or technological knowledge is not designed to make, or replace, binding decisions, but to prepare them. If successful, such assessments produce common expectations about the relevance of the respective environmental problem and the availability of technical solutions. Whereas political decisions are founded upon interests in terms of costs and benefits, scientific and technological assessments generate reliable knowledge that helps shape preferences.

The informal power of scientific and technological assessment processes originates from the fact that convincing information is difficult for policymakers to ignore. Information that has been validated within the treaty system acquires the status of accepted evidence about the significance of an environmental problem, the particular role of a given country or the availability of certain solutions to an environmental problem. Hence, even actors intending exclusively to maximize their own utility might be inclined to change their preferences if they learn about additional 
implications of an environmental problem. Moreover, it becomes more difficult for a reluctant country to pursue the strategy of rejecting stringent pollution abatement measures, if a common assessment based upon an accepted methodology has proven the country to be an exporter of pollutants to neighbouring states. And a defensive strategy rejecting measures to protect the ozone layer cannot be justified by the lack of suitable substitutes for ozone-depleting substances, once the collective assessment process has revealed that such substitutes exist. In essence, the assessment of scientific and technological knowledge forces negotiators either to openly pursue parochial interests or to agree to the scientifically necessary and the technologically possible.

To the extent that scientific and technological assessment gains influence, it helps 'rationalize' the law-making process. Environmental law-making is not entirely determined by inter-governmental bargaining any more. Part of the process is withdrawn from the immediate grip of parochial state interests and submitted to expert reasoning, which tends to be based on the exchange of convincing arguments rather than bargaining power. This does not mean that ensuing substantive obligations lack political consent by the contracting parties. Rather, states are dragged into a collective learning process from which it is difficult to escape, leading state preferences to be adjusted accordingly.

\section{Resulting Legal Structure OF ENVIRONMENTAL TREATY SYSTEMS}

The dynamic regulatory approach of environmental treaty systems has immediate implications for the evolution of international environmental law. Its development is subject to two contradictory principles. On the one hand, international treaty law cannot bind states without their consent, if only because such rules would be difficult to enforce in the absence of a well-organized enforcement power. On the other hand, this principle of state consent does not preclude states from deliberately or implicitly assigning certain decision-making competencies to international institutions to expedite collective decision-making, and the entry into force of new obligations, in order to cope with newly arising environmental problems and to exploit new political and technological opportunities for environmental protection. Accordingly, international environmental law evolves both in the traditional manner, through the adoption and revision of treaty law, and in other ways, through various forms of decisions adopted within a treaty system. As a result, the whole package of obligations entered into by states is no longer entirely reflected in treaties. 


\subsection{Normative Development through Traditional Forms of International Law}

In spite of the required flexibility of environmental governance and the rapid evolution of substantive commitments, treaties still constitute the dominant form for the development of specific international environmental law. Soft law is relevant primarily as an intermediate step on the way to binding forms of agreement or as an additional instrument within established treaty systems, but rarely as a substitute for them. States also prefer to codify even the auxiliary and procedural obligations of important framework conventions-for example, the LRTAP Convention, the Vienna Convention, and the UNFCCC - in the form of full-fledged international treaties, although these instruments lack important substantive obligations. To add substantive obligations, they resort increasingly to the adoption of protocols, which formally constitute treaties subsidiary to the respective conventions and are open for ratification or accession only to members of these conventions.

Whereas the adaptation of the primary law of environmental treaty systems to new requirements occurs generally according to the established procedures for the amendment of international treaties, environmental treaty systems increasingly internalize the necessary institutional functions. Initially, the development of treaty law both in the form of amendments of existing treaties and the adoption of protocols was assigned to diplomatic conferences convened outside the organizational apparatus of a treaty system. This is still formally true for the Barcelona Convention and the LRTAP Convention. ${ }^{23}$ Later treaty systems such as the Vienna Convention, Basel Convention, CBD, and UNFCCC assign the task of preparing and adopting amendments and protocols to their respective COPs. ${ }^{24}$ Upon entry into force of an amendment in 1987, the COP of the Ramsar Convention became formally involved in treaty amendments. ${ }^{25}$ Normally, an amendment or a new protocol must be decided upon by a certain majority of members of the treaty, frequently a two-thirds or a three-fourths majority, and they do not enter into force until ratified by a specified number of parties and only for those parties that have ratified.

Regular amendments are rarely employed to develop key substantive obligations. More frequently, treaties are amended to modify governance arrangements, such as establishing the COP of the Ramsar Convention and introducing a procedure for the amendment of the instrument, allowing the European Community to become a party to CITES, ${ }^{26}$ and establishing the multilateral fund of the Montreal Protocol on

23 See LRTAP Convention, Article 12 ; and Barcelona Convention, Articles 15 and 16.

24 See Convention for the Protection of the Ozone Layer, Articles 8 and 9; Convention on the Control of Transboundary Movement of Hazardous Wastes (Basel Convention), Articles 15 and 17; Convention on Biological Diversity, Articles 28-9; and UN Framework Convention on Climate Change, Articles 15 and 17.

25 M.J. Bowman, 'The Ramsar Convention Comes of Age' (1995) 42 Netherlands Int'l L. Rev. 1 at $33^{-8 .}$

26 See 1982 Bonn Amendment to Convention on International Trade in Endangered Species of Wild Flora and Fauna (CITES); 1983 Gaborone Amendment to CITES; 1982 Paris Protocol to Convention on 
a permanent basis, which paved the way for the accession of a number of important developing countries. ${ }^{27}$ The most important exception to this rule is the Montreal Protocol, which has been amended repeatedly to broaden and tighten obligations to reduce and phase out the production and consumption of ozone-depleting substances. Likewise, the regulatory approach of the Basel Convention towards the transboundary movement of hazardous wastes was transformed from a licensing system into a complete prohibition of exports from OECD countries to non-OECD countries by the amendment of 1995 , after doubts as to whether a simple decision would suffice. ${ }^{28}$

Due to domestic ratification requirements, the development of environmental treaty systems through regular amendments and the adoption of subsidiary protocols is cumbersome and time-consuming. New obligations usually require several years to become effective. The Kyoto Protocol entered into force about seven years after its adoption in 1998, and the 1995 amendment of the Basel Convention still had not entered into force as of August 2006. To accelerate normative development, the members of the Montreal Protocol lowered the threshold for the entry into force of the London Amendments. Whereas the Vienna Convention would have required ratification by two-thirds of the Montreal Protocol parties - that is, 38 ratifications - the London Amendment provided for its entry into force upon ratification by only 20 states.

Since each amendment binds only those states that accept it, amendments create a treaty regime with different memberships for the different instruments, making it increasingly difficult to identify reciprocal commitments. For example, the amendments of the Montreal Protocol of 1990, 1992, 1997, and 1999 were, as of 22 November 2004 , in force for $175,164,121$, and 84 of the 188 members of the protocol. ${ }^{29}$ In very rare cases, this problem may be solved by the winding up of an existing institution and the creation of a new one. For example, key members of the 1971 International Convention on the Establishment of an International Fund for Compensation for Oil Pollution Damage adopted a protocol in 1992 that created a new fund. They also withdrew their commitments from the original arrangement in order to force reluctant members to join the 1992 fund with an adapted scheme of financial compensation for environmental damage from oil spills caused by tankers. ${ }^{30}$ Likewise, the

Wetlands of International Importance, Especially as Waterfowl Habitat (Ramsar Convention); 1987 Regina Amendment to the Ramsar Convention.

27 See R.E. Benedick, Ozone Diplomacy: New Directions in Safeguarding the Planet (Cambridge, MA: Harvard University Press, 1998) at 183-8.

${ }^{28} 1995$ Ban Amendment to the Basel Convention, Decision III/1, Decisions Adopted by the Third Meeting of the Conference of the Parties to the Basel Convention, Doc. UNEP/CHW.3/35 (28 November 1995).

${ }^{29}$ Decision XVI/1, Report of the Sixteenth Meeting of the Parties to the Montreal Protocol on Substances That Deplete the Ozone Layer, Doc. UNEP/OzL.Pro.16/17 (2004) at 42.

${ }^{30}$ M. Jacobbson, 'Oil Pollution Liability and Compensation: An International Regime' (1996) 1 Uniform L. Rev. 260 at 270. 
Uruguay Round negotiations that established the WTO replaced the 'a la carte' approach introduced by the Tokyo Round agreements into the 1947 General Agreement on Tariffs and Trade, under which states could pick and choose which agreements to accept, with a single package of agreements that binds all WTO members. ${ }^{31}$ It is a prerequisite for this strategy that the newly created institution generates sufficient excludable benefits that can be enjoyed only by its members. This condition is frequently not fulfilled in international environmental governance. In the case of regimes that protect a global or a regional commons, such as the ozone layer or a regional sea, replacing an existing treaty system with a new one might encourage reluctant states to refrain from joining the new institution rather than to accept its tightened obligations.

\subsection{Normative Development through Simplified Amendment Procedures}

Some treaty systems rely heavily on simplified procedures for the amendment of technical annexes because the regular procedure for the making and amendment of international treaty law has proven to be too slow to cope with the demand for rapid regulatory change. ${ }^{32}$ Under such procedures, amendments are elaborated by the COPs and must be adopted by specific majorities of parties. However, in contrast to regular amendments, these amendments to annexes enter into force automatically after a specified period of time-frequently 90 days-for all member states that do not object. Aside from this simple opting-out procedure, modified procedures have developed. Under the 1992 Baltic Sea Convention, the amendment of an annex enters into force only if no member state objects. In other cases, amendments enter into force unless a certain number of member states object. For the 1979 Convention on the Conservation of European Wildlife and Natural Habitats, the quorum is onethird of the parties; for the 1992 Convention on Transboundary Effects of Industrial Accidents, it is 16 states. Under the 1946 Whaling Convention, if one member state opts out, the period of time to opt out is automatically prolonged for the other members. ${ }^{33}$ These procedures are designed to ensure that a member state will not be committed to an amendment while other parties, possibly competitors, reject the new obligation.

Although simplified amendment procedures have been designed for the adaptation of technical details, this does not imply that these aspects are less important.

\footnotetext{
31 J.H. Jackson, The World Trading System: Law and Policy of International Economic Relations London (Cambridge, MA: MIT Press, 1999) at 46-9.

32 P. Contini and P.H. Sand, 'Methods to Expedite Environmental Protection: International Ecostandards' (1972) 66 A.J.I.L. 37 .

${ }^{33}$ See 1992 Convention on the Protection of the Marine Environment of the Baltic Sea Area, Article 32; Convention on the Conservation of European Wildlife and Natural Habitats, Article 17; Convention
} 
Occasionally, allegedly technical annexes spell out core components of a treaty system. Especially some conventions adopted in the early 1970 s or before are composed of a very general main body and annexes that are subject to simplified amendment and that set forth detailed regulatory rules. For example, the Whaling Convention authorizes the International Whaling Commission to amend from time to time the annex comprising the measures for the protection of whales ('the schedule'). Likewise, the prohibition or restriction of international trade in endangered species of flora and fauna under CITES requires that species are classified as endangered or threatened. While classification decisions are subject to simplified amendment, they are occasionally highly contentious, especially if they address economically or socially important species such as certain whales or elephants and their products. Similarly, the Consultative Meeting of the London Convention could introduce, by modifying its annexes according to simplified amendment procedures, far-reaching and politically contentious new obligations to restrict and later prohibit the incineration of wastes at sea, and to phase out the dumping of industrial and radioactive wastes as an elaboration of the general obligation to prohibit the disposal of wastes at sea. Decisions of this kind are not merely of technical concern, but they are also highly political and touch upon major interests of member states.

Particularly far-reaching is the adjustment procedure of the Montreal Protocol. Under this procedure, the MOP is empowered to 'adjust', in practice to tighten, reduction targets for ozone-depleting substances that are already regulated under the protocol (Article 2.9). Adjustments enter into force for all parties six months after the decision. Parties shall make efforts for adoption by consensus, but an adjustment may also be adopted by a two-thirds majority of the parties present and voting, which must include simple majorities of both developing and developed countries. Hence, decisions become automatically legally binding even for member states that might have voted against the adjustment. Acceptance of this procedure by the member states can be attributed to particular circumstances that limit the political risk inherent in the approach. At the time it was adopted, the ozonedepleting substances in question were well known and it had been clear to negotiators that they were going to be phased out in the foreseeable future. ${ }^{34}$ The conceptual importance of this procedure stems from the fact that it combines mandatory law-making by a MOP with majority voting. However, the procedure might have pushed the simplification of the amendment of international treaty law a step too far. Not only have all adjustment decisions so far been taken by consensus, the procedure also has not been included in any other treaty system, as far as can be seen.

on Transboundary Effects of Industrial Accidents, Article 26; and International Convention for the Regulation of Whaling, Article 5.

${ }^{34}$ Benedick, see note 27 above at 90. 
The simplified amendment procedures of environmental treaty systems do not introduce a hierarchy of laws in which those parts subject to traditional amendment procedures, and thus under tighter control of the contracting parties, were superior to those parts subject to COP decision-making. Hierarchies of laws are well known from international organizations. Whereas the Charter of the United Nations assigns decision-making competencies to the Security Council, decisions of this body constitute secondary law that does not modify the Charter itself. It is thus remarkable that the COPs of some environmental treaty systems are entitled to change international treaty law, especially the annexes to environmental treaties, and, in the exceptional case of the Montreal Protocol, even possibly against the expressed will of dissenting states.

De facto, if not de jure, simplified amendment procedures delegate law-making functions to the COPs of environmental treaty systems, even if dissenting parties normally enjoy the right to opt out. Inaction under a simplified amendment procedure with an opt-out clause may be interpreted as implicit consent with a decision. ${ }^{35}$ Yet, this interpretation seems to be more directed at preserving the principle of sovereign consent enshrined in international law than at accounting for the particular nature of this form of law-making. In fact, simplified amendment procedures, whether or not they contain an opt-out clause, transfer the necessary activity of law-making from individual to collective action. ${ }^{36}$ Whereas international treaty law usually requires ratification by each individual state that agrees to be committed, under simplified amendment procedures new legal requirements emerge from the collective decision of the competent treaty body. According to both procedures, states cannot usually be bound against their will, but under simplified amendment procedures, indifferent or inactive member states become committed by decisions without individual action.

The importance of some annexes that are subject to simplified amendment procedures and the fact that these procedures create international treaty law may have led to a move away from this approach as the principal means of developing environmental treaty systems. In contrast to the conventions established in the early 1970 , such as CITES and the London Convention, later treaty systems restrict simplified amendment procedures to truly technical details lacking overwhelming general concern-with the just-mentioned limited exception of the adjustment procedure of the Montreal Protocol. As discussed earlier in this chapter (section 2.1), the conventionprotocol approach replaced the convention-annex approach as the major flexibility mechanism for the making of treaty law, as exemplified in the Barcelona and LRTAP Convention systems.

\footnotetext{
35 J. Brunnée, 'COPing with Consent: Law-Making under Multilateral Environmental Agreements' (2002) 15 Leiden J. Int'l L. 1 at $18-20$.

36 B. Simma, 'From Bilateralism to Community Interest' (1994-VI) 250 Recueil des cours 217 at $329-30$.
} 


\subsection{Normative Development through Secondary Decision-Making}

To the extent that decisions of environmental treaty systems are not directed at modifying existing, or at creating new, treaty law, they contribute to a rapidly growing body of system-specific secondary rules that are of tremendous importance in some areas of international environmental governance. In these cases, the flexibility of treaty systems is achieved through the formal or de facto delegation to the treaty's institutions of powers to adopt secondary decisions. Such competencies automatically establish a two-tier hierarchy of obligations. Whereas the treaty at the constitutional level remains under the tight control of the member states collectively and, with the exceptions discussed in section 3.2, also individually through national ratification, a separate body of secondary rules emerges that depends on, and is thus subsidiary to, the treaty. This body of secondary law is generated according to procedures

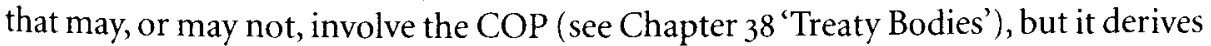
its legitimacy and binding force from the superior treaty and from agreement among the member states.

The formal legal status of secondary decisions is ambiguous and disputed. Under the law of international treaties, secondary law-making is not specifically addressed, except insofar as the contracting parties may agree on common interpretations of a treaty and on its provisional application prior to its formal entry into force. ${ }^{37}$ Accordingly, authoritative interpretations by the COPs of environmental treaty systems designed to close unintended gaps of treaty law may be assumed to be legally binding at least for consenting states. ${ }^{38}$ Moreover, secondary decisions that are explicitly assigned to a decision-making body by the constituent treaties might also acquire full legal status, if treaty language suggests that legally binding force was intended by the contracting parties. ${ }^{39}$ For example, the MOP of the Montreal Protocol was explicitly empowered to consider the feasibility of, and adopt, trade measures concerning products containing, or produced with, ozone-depleting substances (Article 8) and to elaborate the non-compliance procedure. The Kyoto Protocol explicitly assigns a whole range of tasks to the COP/MOP of the treaty system, which may have far-reaching implications and amount in fact to an exercise in legislation, rather than to the mere interpretation of treaty law. Due to their hybrid structure, environmental treaty systems might also fall under the law of international organizations, under which competent bodies can adopt legally binding internal

\footnotetext{
37 See Vienna Convention on the Law of Treaties, Articles 31 and 25.

38 See J. Sommer, 'Environmental Law-Making by International Organizations' (1996) 56 Zeitschrift für ausländisches öffentliches Recht und Völkerrecht 628 at 637-8.

39 See V. Röben, 'Institutional Developments under Modern International Environmental Agreements' (2000) 4 Max Planck Y.B. UN L. 363 at $404-5$.
} 
decisions by the required majorities of parties present and voting. ${ }^{40}$ Many important substantive decisions might be considered as internal to the legal order of the treaty system, even if they unfold certain external effects.

Remarkably, the drafters of the treaties tend to avoid express statements on the legal status of decisions. Whereas many decisions may easily be conceived of as legally binding interpretations of treaty provisions, others develop treaty systems considerably without being explicitly provided for in treaty law. The contracting parties seem to accept the ambiguous legal status of many secondary rules in exchange for the ability to employ secondary decision-making as a mechanism for the rapid development of environmental treaty systems. When an interim multilateral fund was established by the MOP of the Montreal Protocol by a simple 'decision', there was no discussion about the legal status of this instrument. ${ }^{41}$ Likewise, upon adoption of the noncompliance procedure of the Montreal Protocol, the MOP expressly accepted the recommendation of the Legal Expert Group 'that there is no need to expedite the amendment procedure' under the Vienna Convention, ${ }^{42}$ suggesting that, even in the absence of amendment, non-compliance decisions would have sufficient legal authority. Without a specific competence, the COP of CITES has, over time, adopted various decisions that are apparently intended to, and seem to be regarded as, legally binding. Perhaps the most important of these decisions is the introduction of quota systems for various animal products such as ivory. ${ }^{43}$ In contrast, some parties argued that the decision of the COP of the Basel Convention to ban exports of hazardous wastes from OECD countries to non-OECD countries was not legally binding because the COP could not alter the parties' substantive obligations. ${ }^{44}$ Whereas the decision is therefore widely considered as reflecting political, rather than formal legal, commitment, the clear wording ('the Conference ... decides to prohibit all transboundary movements of hazardous wastes'), and the fact that it was adopted by consensus after contentious negotiations, suggest that the contracting parties nevertheless expected that it would be adhered to, and thus considered that the COP had the authority to commit the member states, even if not in legal terms.

Within a particular treaty system, decisions will generally gain de facto binding force, if commitment is intended by the community of member states. The precise legal status of secondary rules is of comparatively little importance for the practical

10 R.R. Churchill and G. Ulfstein, Autonomous Institutional Arrangements in Multilateral Environmental Agreements: A Little-Noticed Phenomenon in International Law' (2000) 94 A.J.I.L. 623
dt $631-58$.

41 Gehring, see note 11 above at 318

42 Decision IV/5 (1992), Report of the Fourth Meeting of the Parties to the Montreal Protocol on Substances that Deplete the Ozone Layer, Doc. UNEP/OzL.Pro.4/15 (25 November 1992).

4 P. Sands, Principles of International Environmental Law: Framework, Standards, and Implementation, 2nd edition (Cambridge: Cambridge University Press, 2003) at 513-14.

${ }^{4}$ Report of the Second Meeting of the Conference of the Parties to the Basel Convention on the Control of Transboundary Movements of Hazardous Wastes and Their Disposal, Doc. UNEP/CHW.2/30 (25 March 1994) at paras. 39-50 and Decision II/12; see L. de la Fayette, 'Legal and Practical Implications of the Ban Amendment to the Basel Convention' (1995) 6 Y.B. Int'l Envt'l L. 703 at $705-8$. 
operation of environmental treaty systems. The contracting parties can, therefore, afford to avoid determining the issue of legal status. They tend to do so, because principled discussion in this regard might jeopardize the successful reliance on decisions as a means of governance that is more flexible than regular treaty law, and at the same time able to commit the member states more intensely than mere recommendations. Therefore, they can employ the instrument of a firmly worded decision even in cases that reach far beyond their undisputed law-making authority.

The commitment effect of decisions originates, first of all, from the consent of the contracting parties. ${ }^{45} \mathrm{~A}$ decision that attracts the broad support of all or at least most member states reflects a promise of the supporters to honour their mutual commitment. Breaking such a promise undermines a state's reputation because offenders appear as unreliable cooperators. Therefore, the contracting parties in most environmental treaty systems seek to adopt important, if not all, secondary decisions by consensus so as to extend the consent-based binding force to all parties, even if adoption by simple or qualified majority is formally possible.

Second, such decisions may be part of larger package deals among the contracting parties and cannot be ignored without jeopardizing the whole package. In many cases, international governance depends on package deals that combine different issues, each of which is advantageous for a different group of actors. In this case, all contracting parties will be aware of the fact that ex post withdrawal from undesired parts of the package may prompt the withdrawal of other parties from their obligations. Accordingly, member states with an interest in a given treaty system will accept and be prepared to implement ensuing obligations irrespective of their exact legal status. Hence, whether contributions to the multi-million dollar interim multilateral fund of the Montreal Protocol were considered as legally binding or not, contributing countries could not withdraw from their commitments without risking the noncompliance of important developing countries. ${ }^{46}$ And the ban of the transboundary movement of hazardous wastes from OECD countries to non-OECD countries was the precondition for the universal acceptance of the Basel treaty system.

Third, secondary decisions may change the situation even for actors that dislike the content of the decisions, so that unilateral rejection is not a viable option. ${ }^{47}$ If provisions for the assessment of production and consumption figures under the Montreal Protocol, criteria for the classification of endangered species under CITES, or the rules of the clean development mechanism under the Kyoto Protocol are formulated in a particular way that has been agreed upon within the relevant COP or MOP, the treaty systems will simply operate accordingly. Alternative options are excluded by the decision, so that, unless a member state is willing to leave the system, it is forced to accept the operation of the system as it is.

${ }^{45}$ See B. Simma, 'Consent. Strains in the Treaty System,' in R. St. J. MacDonald and D.M. Johnston, eds., The Structure and Process of International Law: Essays in Legal Philosophy, Doctrine and Theory (The Hague: Martinus Nijhoff, 1983) at 495-7.

47 Brunnée, see note 35 above at $23-31$.

46 See Benedick, see note 27 above at 188-90. 
Fourth, environmental treaty systems replace the traditional procedures of litigation and dispute settlement under the rules of international law with internal mechanisms of norm interpretation and compliance control. The formal legal status of a decision accepted by the member states will not be relevant, unless a conflict over its content and consequences is arbitrated or litigated outside the treaty system. Whereas several environmental treaty systems explicitly envisage traditional international procedures for the settlement of conflicts, such as conciliation, third-party arbitration, or adjudication, these procedures have been used only in very few cases so far, and they are unlikely to be employed more widely in the future. Apart from being too confrontational, they do not account for the specificities of a particular treaty system. In particular, they risk involuntarily unravelling package agreements, if they dishonour informal parts of the treaty system. Instead, starting with the Montreal Protocol, several environmental treaty systems have developed their own mechanisms for implementation control and dispute settlement (see Chapter 43 'Compliance Procedures'). These quasi-judicial mechanisms reflect the desire of contracting parties to internalize the function of dealing with disputes about compliance into the overall collective decision-process of the respective treaty systems.

Finally, environmental treaty systems may develop their own internal sanctioning instruments to thwart their gradual unraveling through the 'selective exit' of contracting parties from undesired obligations. Particularly relevant are privileges granted only under the condition that obligations are fulfilled. The indicative list of measures' available in case of non-compliance adopted under the Montreal Protocol includes, besides assistance and the issuing of cautions, the possible 'suspension... of specific rights and privileges under the Protocol ... including those concerned with industrial rationalization, production, consumption, trade, transfer of technology, financial mechanism and institutional arrangements. ${ }^{\mathbf{4}}$ These measures are directed at withdrawing privileges enjoyed by the member states under the protocol, and the MOP has cautioned a number of countries in transition that it might invoke them. ${ }^{49}$ Privileges granted under the Kyoto Protocol include, beside financial and technological assistance, the employment of the flexibility mechanisms, namely the clean development mechanism, joint implementation, and emissions trading, to reduce implementation costs. Their use currently requires that countries meet eligibility criteria, and the suspension of eligibility in cases of non-compliance might become a major sanctioning instrument of the treaty system.

The increasingly wide use of decisions by a treaty's institutions as a governance instrument that can generate commitment among the member states contributes significantly to the flexibility of modern environmental treaty systems. Whereas

\footnotetext{
48 Report of the Fourth Meeting of the Parties to the Montreal Protocol on Substances that Deplete the Ozone Layer, Doc. UNEP/OzL.Pro.4/15 (25 November 1992), Annex V.

49 For example, MOP Decisions X/20,21,23-28, Report of the Tenth Meeting of the Parties to the Montreal Protocol on Substances that Deplete the Ozone Layer, Doc. UNEP/OzL.Pro.10/9 (3 December 1998 ).
} 
the making of environmental treaty law has become less flexible over time especially due to the replacement of the convention-annex approach by the more traditional convention-protocol approach, environmental treaty systems do not seem to be less flexible than before. The more traditional form of treaty-law making is complemented by the increasing use of highly flexible secondary decisions. In spite of their often unclear, and occasionally disputed, formal legal status, such decisions reflect an important part of the entire package of obligations faced by the member states of many environmental treaty systems. As long as the commitments reflected in these decisions are, within their respective treaty systems, not treated significantly different from commitments enshrined in formal treaty law, they will be honoured by the member states equally well.

\section{Conclusion}

The making and evolution of international environmental law are related to the establishment of numerous separately institutionalized multilateral treaty systems. Treaty systems are negotiated and adopted predominantly within the framework of existing international organizations or similar institutions. Upon their establishment, they become machineries for the making of new law and for the development of existing law in their respective areas of competence. One characteristic of the making and development of international environmental law is the fragmentation of the institutional setting from which it emerges. Environmental treaty systems govern comparatively small areas of international relations. Apparently, the contracting parties prefer the establishment of new treaty systems to the linkage of new environmental problems to existing systems. As a second characteristic, environmental treaty systems comprise, like international organizations, a permanent institutional component that enables the contracting parties to adjust obligations as necessary or appropriate to new circumstances as well as to supervise implementation and react collectively to cases of non-compliance.

In contrast to other areas of international governance, international environmental governance decidedly relies upon a step-by-step approach, and almost all important treaty systems have considerably developed over time. Through their scientific and technological apparatus for the assessment of governance-related facts, treaty systems comprise arrangements directed at creating new opportunities for cooperation among the contracting parties. Moreover, they have developed different institutional devices for the accelerated entry into force of new obligations. These arrangements include simplified amendment procedures, the adoption of secondary decisions that elaborate treaty law, the resort to soft law instruments if legally binding obligations cannot be agreed upon, and interim mechanisms to 
bridge the occasionally long period until a new treaty or amendment enters into force.

Environmental treaty systems partially transform intergovernmental bargaining into deliberative transnational problem-solving processes. Essentially, policy-making within environmental treaty systems remains based upon inter-governmental negotiations, and states must be assumed to pursue predominantly their parochial interests. However, assessments of scientific and technological knowledge introduce, if successfully operating, a sphere of technical deliberation into the bargaining process. Improved and collectively validated knowledge about the scope and implications of an environmental problem or about the availability of technological solutions contributes to the gradual modification of state preferences, which in turn can lead to agreement on new commitments. Moreover, the most advanced environmental treaty systems increasingly rely on the delegation of implementation decisions to specifically structured procedures that are directed at the application of general normative criteria, and avoid the mere balancing of state interests. If operating successfully, such procedures can create a process of normative deliberation.

As a result of these far-reaching internal law-making activities, the whole package of obligations entered into by the contracting parties to an environmental treaty system is no longer entirely reflected in the text of the treaty. Although the major substantive and procedural obligations remain enshrined in international treaty law, additional rules and implementation decisions add up to system-specific bodies of secondary law. Irrespective of the formal legal status of these rules, environmental treaty systems operate on the assumption that decisions that are meant to be mandatory are accepted as commitments by the parties. Moreover, the contracting parties frequently refrain from clarifying the legal status of the decisions, because this endeavour might jeopardize the use of secondary decision-making altogether. As long as they abstain from external litigation and arbitration, they remain the masters of the process, defining collectively what they are prepared to accept and which obligations they expect others to observe. As a consequence, environmental treaty systems become autonomous sectoral systems of international law, which increasingly internalize the management of conflicts about the interpretation of commitments as well as the treatment of cases of non-compliance.

\section{RECOMMENDED READING}

R.E. Benedick, Ozone Diplomacy: New Directions in Safeguarding the Planet (Cambridge, MA: Harvard University Press, 1995).

F. Biermann and S. Bauer, eds., A World Environment Organization: Solution or Threat for Effective International Environmental Governance? (Aldershot: Ashgate, 2005).

D. Bodansky, 'The Legitimacy of International Governance: A Coming Challenge for International Environmental Law?'(1999) 93 A.J.I.L. 596. 
J. Brunnée, 'COPing with Consent: Law-making under Multilateral Environmental Agreements' (2002) 15 Leiden J. Int'l L. 1.

R.R. Churchill and G. Ulfstein 'Autonomous Institutional Arrangements in Multilateral Environmental Agreements: A Little-Noticed Phenomenon in International Law' (2000) 94 A.J.I.L. 623 .

G.W. Downs, K.W. Danish, and P.N. Barsoom 'The Transformational Model of International Regime Design: Triumph of Hope or Experience ?'(2000) 38 Colum. J. Transnat'l L. 465.

T. Gehring, Dynamic International Regimes: Institutions for International Environmental Governance (Frankfurt: Peter Lang, 1994).

L.E. Susskind, Environmental Diplomacy: Negotiating More Effective Global Agreements (Oxford: Oxford University Press, 1994).

D.G. Victor, K. Raustiala, and E.B. Skolnikoff, eds., The Implementation and Effectiveness of International Environmental Commitments: Theory and Practice (Cambridge, MA: MIT Press, 1998).

W. Wijnsteckers, The Evolution of CITES: A Reference to the Convention on International Trade in Endangered Species, 8th edition (Geneva: CITES, 2006). 